\title{
The Student's Attitude toward Use Platform as Learning Resources at University of Granada
}

\author{
Dr. Ahmad Alobiedat (Corresponding author) \\ Faculty of Education, Tafila Technical University \\ Tafila - Jordan \\ P.O. Box 179 Zip code 66110- Jordan \\ Tel: 962-77-727-1789_E-mail: alobiedat@yahoo.com \\ Dr. Raji Saraierh \\ Faculty of Education, Tafila Technical University \\ Tafila - Jordan \\ P.O. Box 179 Zip code 66110- Jordan \\ Tel: 962-79-902-7886 E-mail: raji_awad_888@yahoo.com
}

\begin{abstract}
The study aim to investigate students' attitudes towards use platform as learning resources at University of Granada (UGr), a survey of two hundred fifty-eight male and female undergraduate students from faculty of education, were randomly selected to participate in the study. The results of the study shows a positive attitude toward use of platform as learning resources and there was a significance difference, due to the gender, owning a personal computer (PC), and having access to the internet, and it was in favor of male students, and student who own a pc, and student whom do have access to the internet respectively.
\end{abstract}

Keywords: Attitude, Platform, University of Granada, Learning resource, Information technology

\section{Introduction}

The traditional education delivery system has been a classroom setting with a professor giving a lecture and students listening and writing notes. Interaction between the professor and student has been viewed as an essential learning element within this arrangement. However, innovations in educational technology use of platform as delivery mechanisms have challenged this paradigm. Advances in Information Technology (IT) are enabling little used educational delivery methods such as Distance Learning (DL) to gain new life. In addition, the advances in IT have ushered in a new paradigm, On-line Learning (OL). The result is that many universities have adopted distance and on-line education as the next logical step in educational delivery systems. These systems are being promoted as the educational pedagogy of the future. Some experts have gone as far as to predict that the "residential based model," that is, students attending classes at prearranged times and locations will disappear in the near future (Blustain, Goldstein, and Lozier 1999 and Drucker 1997). However, one overriding question that must be addressed is how will these new educational delivery approaches that move away from the basic face to face relationship between a professor and students impact student learning and student attitudes of learning. Most university students will participate in two distinct forms of networked communication. (Ofcom 2008) and (Crook 2008) in their study, universities will engage with their institutional learning platform, or virtual learning environment (VLE), while numerous reviews now suggest, they will also engage with those internet services collectively termed 'Web 2.0 in particular social networking sites such as Facebook. VLEs now pervade all sectors of education (DfES 2005). Accordingly, their effective design is a matter of serious concern. Where a VLE is adopted, it has become clear for higher education that the resource is rarely used very creatively. Woods, Baker and Hopper (2004) surveyed over 800 members of faculty at 38 US institutions. The dominant use of VLEs was as a convenient repository for familiar course documents and resources. Morgan (2003) surveyed a similar number of US academics and closely interviewed 140 others. They report the same pattern, and comment: 'faculty adopts course management systems principally to manage the more mundane tasks associated with teaching, especially teaching large classes'. Yet most platforms do provide tools and designs that allow tests, chat dialogue, discussions, blogs, FAQs, notice boards and so forth. Malkowski, Thompson and Theis (2006) considered how far these were 
actually taken up in a volunteer sample of 87 faculty members at a US university. Only 3 out of 13 interactive design features were used by more than half of this group: 'faculty members primarily use a CMS to transmit information to students' (171). To systematize what teachers create, Dutton, Cheong, and Park 2003). At many universities, the effectiveness use of the use platform, distance and on-line learning methodologies has not been well researched prior to adoption. To better understand how these learning technologies and its impact on student attitudes toward e-learning, this study was conducted at UGr. The goal of this research study is to understand faculty of education student's attitude toward use platform as learning resources at UGr. In addition, in this research paper investigative the effect use platform as learning resources on gender, owning PC, and access to the internet.

\section{Literature Review}

Alternatives to traditional lecture style delivery of education have been offered for many years (Huang, 1996-1997). These alternatives, called online learning education, became available with the development of a reliable mail delivery system during the late nineteenth century (Ascough, 2002; Rumble, 2001). Distance learning has been defined as any approach to education delivery that replaces the same time, same place, face to face environment of a traditional classroom (Volery \& Lord, 2000). According to this definition, distance education can take many forms such as mail correspondence, open and closed circuit audio and video presentations, telephone communications, and the increasingly popular Internet. With these alternatives, however, students are able to attain an education even if they live a great distance from an educational institution or when their respective campus does not offer desired courses (McLester, 2002). The advances in computer technology, particularly the development of the Internet, have improved the delivery of distance education. Many universities are developing and offering a multitude of courses designed to be taught using Internet services. With broadening horizons and the expanding utility of Internet resources available to universities and consumers, the potential for this form of education and lifelong learning has become more accessible. In fact, from 2003 to 2004, online learners in the United States increased from 1.98 million to 2.35 million (Allen \& Seamen, 2005). Distance education is appealing for many reasons. Foremost, online courses do not require regular Attendance at scheduled lectures. Thus, those working fulltime or who have other responsibilities are drawn to online courses, as is the case with many non-traditional students. Another convenience of online education is the ability for students to learn materials at their own pace. Many online courses are presented in an asynchronous manner where materials are time and place independent allowing students to access course materials at any time (Newlin \&Wang, 2002). In these instances, instructors can be contacted with a simple email, and students can receive feedback quickly. Online courses usually still have project due dates and examinations, but these courses generally provide students with flexible course options. Although the advantages of online education are appealing, there are also disadvantages. For those who have never taken an online course or who have little computer experience, an online course may be frightening. For example, Wang, Newlin, and Tucker (2001) found that many web based students expressed feelings of intense anxiety about the technology. There are also disadvantages in online courses for individuals who need a great deal of structure. Online courses are frequently self paced and those lacking self discipline may struggle. However, these advantages and disadvantages are highly individual and should be considered by each individual learner. Assignments and homework is an important component of introductory instruction at the university level. An effective method of student assessment is necessary in university as well as all areas and levels of education. In the traditional formal classroom, assessment has been conducted with paper and pencil using questioning techniques such as multiple choice, constructed response, fill-in-the blank, and essay items. This type of testing has been used to assess the skills and knowledge of students since the early 1930s (Hatfield \& Gorman, 2000). Advancements in technology have led to new methods of delivering information and student assessment. With the evolution of web-based technologies and the broad availability of computers, student assessment can now include computer-based forms. However, use platform homework system has some benefits. These benefits include obtaining students' results faster, having the ability to place grades into electronic format, measuring learning accurately, focusing on a student-centred environment, and costing less compared to paper-based exams (Bartlett, Reynolds, \& Alexander, 2000; Dash, 2000; Oregon to Administer, 2001). Student using different kinds of the use platform s such as Module, WebCT, Blackboard as an e-learning tool has grown tremendously over the past several years as technology has been integrated into education and training. "E-learning" may be defined as instruction delivered electronically via the Internet, Intranets, or multimedia use platform s such as CD-ROM or DVD (Hall, 2003; O'Neill, Singh, \& O'Donoghue, 2004). Since many users today have access to direct Internet connections, e-learning is often identified with web-based learning (Hall, 2003). Many writers refer to "e-learning," "online learning," "web-based learning" SWAD Use platform means in Spanish Web system to help in teaching (Sistema Web de Apoyo a la Docencia) (SWAD) interchangeably, an approach that will be taken in this paper. E-learning can be implemented in a variety of ways, such as through the 
use of self-paced independent study units, asynchronous interactive sessions (where participants interact at different times) or synchronous interactive settings (where learners meet in real time) (Ryan, 2001). Although some universities now days are offering an e-learning class that blended approaches that integrate online components into traditional classes, it still remains at an early stage of development. Consequently, developers and deliverers of online learning need more understanding of how students perceive and react to elements of e-learning (since student attitude and attitude is critical to motivation and learning) along with how to apply these approaches most effectively to enhance learning (Koohang \& Durante, 2003). What we know about students learning is an important starting point for exploring the use of educational technology and the instructional design and success of use the use platform as an e-learning tool. The basis of effective use platform as an e-learning tool for learning is comparable to the foundation of effective learning in general. Among the many theories surrounding how people learn. Learning theory suggests that learning is promoted or enhanced (1) when students are actively involved in the learning, (2) when assignments reflect real-life contexts and experiences, and (3) when critical thinking or deep learning is promoted through applied and reflective activities (Bransford, Brown, \& Cocking, 2000). The goal of this research is to achieve better understanding for student attitudes toward use platform as learning resources format at UGr, in addition, in this research paper investigative the effect use platform as learning resources on gender, owning a PC, and access to the internet. Numerous studies have demonstrated that a student's active involvement in the learning process enhances learning, a process often referred to as active learning (Benek-Rivera \& Matthews, 2004; Sarason \& Banbury, 2004). Simply stated, active learning involves "instructional activities involving students in doing things and thinking about what they are doing" (Bonwell \& Eisen, 1991, p. 5). Interactive instruction or "learning by doing" has been found to result in positive learning outcomes (Picciano, 2002; Watkins, 2005). Because many new technologies and web-based activities are interactive, using the platform as online coursework has the potential to create environments where students actively engage with material and learn by doing, refining their understanding as they build new knowledge (Johnston, Killion \& Omomen, 2005; Pallof \& Pratt, 2003). As Driscoll (2005) observes, that "When students become active participants in the knowledge construction process, the focus of learning shifts from covering the curriculum to working with ideas". And using technology tools 'to think with' facilitates working with ideas and learning from that process" (Scardamalia 2002). In addition to active involvement, students better understand and apply material when problems and situations are set in the context of real world issues and situations (Eble, 1988). Authentic situations and scenarios can provide a stimulus for learning, creating greater student motivation and excitement for learning, representing and simulating real-world problems and contexts, providing an important structure for student thinking (Quitadamo \& Brown, 2001). Emphasizing authentic tasks in context rather than abstract out-of-context activities creates a greater likelihood of learning (Driscoll \& Carliner, 2005). Technology and online instruction can facilitate learning by providing real-life contexts to engage learners in solving complex problems (Duffy \& Cunningham, 1996; Honebein, 1996). The use of real-world situations has the potential to promote deep learning through the development of critical thinking skills. Critical thinking involves the active and skillful analysis, synthesis, and application of information to unique situations (Scriven \& Paul, 2004). Learning retention and performance improves as students are required to apply what they have learned and then reflect upon the learning (Bransford, Brown, \& Cocking, 2000). Online instruction has the potential to provide opportunities to promote reflective thought and deep learning through realistically integrating and applying principles learned. Online instruction, such as a simulation, thrusts learners into a learning experience, increasing engagement and providing activities that actively engage learners to analyze, synthesize, and evaluate information while constructing knowledge (Driscoll \& Carliner, 2005). Built upon a foundation of learning theory, e-learning can potentially provide many important payoffs. To learners, online instruction offers the flexibility and convenience to complete learning units when and where a learner desires. Additionally, online education has been used to reduce costs and to provide an efficient, standardized way to deliver content (McDonald, 1999-2000; "E-learning," 2003; "The Pay offs," 2003). In addition to potential cost savings, e-learning has pedagogical potential beyond traditional methods related to the principles of learning discussed. For instance, multimedia capabilities can be used with learning exercises that allow learners to apply concepts realistically. Or, animation can help demonstrate concepts and events difficult to portray in traditional classes, which, in turn, can facilitate a more accurate communication of important ideas. E-learning can deliver "new" information not contained in traditional sources, effectively reinforcing other course information through offering examples, explanations, assessments, and exercises. In this way, online instruction can potentially enhance learning compared to what can be accomplished using a classroom only approach (McEwen, 2001). However, there are also potential disadvantages or limitations of online learning. For example, one study concluded that asynchronous e-learning was not effective as a standalone method to deliver technical training for information technology professionals learners in the study commented that e-learning eliminates classroom interaction time, where a significant amount of "real learning" 
takes place as users assimilate information, utilize software, apply knowledge to problem solving, and interact with the instructor and other learners (Laine, 2003). Other potential problems of e-learning that have been identified in previous research include a sense of learner isolation (Brown, 1996); learner frustration, anxiety, and confusion (Hara \& Kling, 2000; Piccoli, Ahmad, \& Ives, 2001); higher student attrition rates (Frankola, 2001; Laine, 2003; Ryan, 2001); the need for greater discipline, writing skills, and self-motivation; and the need for online users to make a time commitment to learning (Golladay, Prybutok, \& Huff, 2000; Serwatka, 2003).

\section{Statement of the problem}

In search of better, more cost effective ways to deliver instruction and training, universities and corporations have expanded their use of e-learning. Although several studies suggest that online education and blended instruction (a "blend" of online and traditional approaches) can be as effective as traditional classroom models, few studies have focused on student use of the use platform as online instruction, particularly in the transition to online learning from traditional approaches. This study aimed to investigate the faculty of education student's at UGr their attitude toward use platform as learning resources, also investigate the effect of use platform as learning resources on the gender, owning PC, and access to the Internet.

\section{Significant of the study}

In the last two decades, Espania education system has been a gradual shift on the emphasis from teacher-centered approach to a student-centered approach. The implementation of the platform program provides further force to transform teacher's role from being the dispenser of knowledge to being the facilitator of learning. The use platform program as technology-supported education system and was introduced to help Espania fulfill the need for an IT-literate population. As the use platform program places major emphasis on the use of IT in classrooms, there is surely a need to shift from the conventional lecture-practice-recall teaching methods to methods where teachers engage students in activities that create opportunities to construct new knowledge and skills (Shelly et al, 2004). The teacher's role changes from that of the sole authority and a sage on the stage to that of a guide at the side and a facilitator (Rakes, 1996; Cifuentes, 1997). At the same time, the student's role shifts from being a passive and dependent learner to being an active and independent learner (Coombs \& Wong, 2000; Hirumi, 2002).

\section{Research question of the study}

The first question: What is the attitude of UGr students' towards use platform as learning resources?

The second question: Is there a statistical significance differences at the level of $(\alpha \leq 0.05)$ in the attitude of UGr students' towards use platform as learning resources due to gender?

The third question: Is there a statistical significance differences at the level of $(\alpha \leq 0.05)$ in the students' attitude towards use platform as learning resources due to the owning PC?

The fourth question: Is there a statistical significance differences at the level of $(\alpha \leq 0.05)$ in the students' attitude towards use platform as learning resources due to access to the Internet?

\section{Methodology}

\subsection{Sample of Study}

The study was conducted at faculty of education at UGr. A random sample of undergraduate male and female students $(\mathrm{N}=258)$, the participants were asked to complete a questionnaire which included items to measure students' attitude toward use platform as learning resource.

\subsection{Development of Instrument}

A 5-point Likert type scale with strongly agree; agree; undecided; disagree; and strongly disagree for the items of the questionnaire, was developed to measure students' attitude toward use platform as learning resource. The questionnaire consisted of two parts the first part consist of the demographic information, the second part consist twenty five items. To verify the reliability of the questionnaire the researchers distributed questionnaire on sample of forty five students out of the original sample and used the internal consistency Cronbach Alpha. The reliability of the scale was 0.84 , and to verify the validity of the questionnaire in terms of objectivity, language, and the number of items, the questionnaire was submitted to panel of referees from faculties of education colleges to revise it, and report their remarks about the items a modification has been made according to the advised by the arbitrators.

\subsection{Analysis and Discussions}

6.3.1 Question one: to answer the question, what is the attitude of UGr students' towards use platform as learning resources? To answer the question, the means, and standard deviations, for the respondents of the study samples 
was computed, the mean was 3.4 and std. deviation was 0.43 , which this means a positive attitude from the students toward use of platform as learning resources. From above, the result indicate that use of platform as learning resources, will alleviate students learning in all of its form aspects, like help student to clarify the understanding, also help student enhanced their interaction between student each other and the faculty, the use platform also might help student organize their study time about the subject content, encouraged students to know more about the subject. Roblyer has found that the capacity to choose when to complete activities is the most important factor in positive student responses to online learning, because it grants students a measure of control over their learning, also community college students enrolled in distance education courses also responded positively to the online format (Roblyer, 1999). Undoubtedly, choice makes a significant difference in students' perceptions. Students who prefer online courses place greater value on their control of the pace of the course than on face-to-face interaction (Roblyer, 1999). In study for Carnevale (2000) he found that distance education students look for many of the same things found in traditional courses including a knowledgeable professor, interaction with the professor, and additional features that create a feeling of community within the class. Schoech (2000) reported that the satisfaction, grades, and performance of students in a semester-long graduate social work course taught in a distance format were consistent with previous outcomes in traditional courses of similar content. A final factor in students' perceptions of online learning is personal contact, some students who learn online report feelings of isolation and loneliness, those students miss the social contact and face-to-face interaction that an institutional setting provides. Additionally, students who lack self-motivation dislike having to motivate themselves to do the coursework. The distance learner may have problems separating "work from home life, experiencing tensions in relations with their family and spouse" (Harrell, 1999, p. 270).

6.3.2 Question two: Is there statistical significance differences at the level of $(\alpha \leq 0.05)$ in the attitude of UGr students' towards the use platform as learning resources due to gender? to answer the question, the means, standard deviations was computed for the students' attitude towards use platform as learning resources, according to the gender, therefore to detect the statistical significant differences between the mean for male and female attitude towards the use of platform as learning resources, independent-sample $\mathrm{T}$ test was used, and the results as shown in table 1 below.

\section{Insert Table ---1 --- Here}

It's clear from the table 1 above the result shows that there are significance differences, due to the gender attitude towards the use platform as learning resources; it was in favor of male students. The interpretation for this result, maybe due those male students prefers use platform method, because it makes learning convenient for them. In addition the nature of male student inpatient and they prefer speed in working with their assignment, the use of platform could create a learning environment that would help them patiently get the assignment done, several researchers studies found that attitudes toward technology differ significantly between males and females student, males indicating greater interest and knowledge with the use of technology, while female students perceived technology as less interesting and more difficult to understand and to use, than male students (Bame et al, 1993; Boser et al, 1998; Heywood, 2000). For example, more males than females perceived their home as being more technological, also more males than females rated both parents' occupations as more technical, their study also mention that males indicated a greater interest and knowledge of computers than females

6.3.3 Question three: Is there statistical significance differences at the level of $(\alpha \leq 0.05)$ in the attitude use platform as learning resources due to the owning PC? to answer the question, the means, standard deviations was computed for the students' attitude towards use platform as learning resources, according to the owning a pc, then to detect if there is a statistical significant differences. Independent-sample $\mathrm{T}$ test was used, and the results as shown in table 2 below.

$$
\text { Insert Table --- } 2 \text {--- Here }
$$

Table 2 above reflect that there is a statistical significance differences due to the owning a pc, it was in favor of student who own a pc, the interpretation this result it could be that owning a pc will give a great chance to the student to use available technology to them at all the times any time on their own pace, several studies found evidence of owing pc differences, virtually every study that did reported the males are more advantaged, males are more likely to own a computer (Schumacher \& Morahan-Martin, 2001). Meanwhile Negative student responses to online learning are also due to owning a computer factor, particularly for students with part-time or full-time jobs, students who do not have an access to use pc or don't have computers in their homes are often irritated by the additional time required to visit a computer lab (Crotty, 2000), a lack of convenience that contributes to working students' negative reactions. Students who own pe they do have the flexibility to use the platform, chats or other synchronous activities that occur at fixed times. Students whom don't own a pc they don't have the flexibility to use 
platform, so those students will be forced to access the platform via computer lab schedule, computer lab availability, therefore their use and their attitude toward use the platform will decrease in general. (Carr, 2000). Other complaints due to don't won a pc, include not having enough time to read and send e-mail and to perform related online activities, also the type of computer access students experience impacts their attitude toward online learning experiences. If students have a computer at home or in their dorm, they may find distance learning activities more convenient than students who have to locate an available computer. Also, an experienced computer user might be more comfortable with publicly available and unfamiliar hardware than a non-user. In a review of a longitudinal study involving more than 800 university students, McMahon, Gardner, Gray, and Mulhern (1999) reported that computer access accounts for $50 \%$ of the variance that exists among student attitudes toward online learning.

6.3.4 Question four: Is there a statistical significance differences at the level of $(\alpha \leq 0.05)$ in the students' towards use platform as learning resources due to access to the internet? To answer the question the means, standard deviations was computed and, then to detect if there is a statistical significant differences. Independent-sample $\mathrm{T}$ test was used, and the results as shown in table 3 below.

$$
\text { Insert Table --- } 3 \text {--- Here }
$$

Table 3 above reflect that there is a statistical significance differences in function at the level of $(\alpha \leq 0.05)$ in the attitude toward use platform as learning resources due to access to the internet, it was in favor of student whom do have access to the internet, this could be interpretation that access to the internet, give a chance to use the technology all the time any time on their own pace. With online learning, students control the factors, when, where, and what they learn, as well as how often and how quickly and this level of control is what creates satisfied students. In a recent study, nearly $68 \%$ of students were "satisfied" or "very satisfied" with using the Internet as the primary source of course materials (Beatty, 2000). Reasons for students' satisfaction ranged from accessibility and convenience to flexibility and student-teacher interaction. Even though technology-related experiences are as varied as the individuals who use computers to access internet, both men and women voice positive attitudes about online learning, student responses also reflect concerns they have due accessing the internet, about hardware issues such as modem speed and available memory. Complaints about the periodic slowness of Internet connections or server problems indicate that such difficulties frustrate students (Harrell, 1999). Computer hardware problems increase student concern about using computer to access internet and the quality of their online learning experience. When the connection is too slow, the server is down, or the memory is full, the computer experience becomes a hindrance to education. Also, students who may already lack confidence in computer equipment transfer their feelings of inadequacy to the learning experience.

\section{Conclusion}

Things emerge in the study of students' attitudes toward use platform as learning resource: individual situations impact students' perceptions of virtual learning and students' individual characteristics make it difficult to define their perceptions conclusively. For example, some students have their own computers, while others rely on computer labs. Such variation in computer access can result in attitudinal attitudes differences. In addition, the purpose of computer use by students varies - distance education courses, for example, use computers in different ways than traditional classroom - which can also affect students' perceptions in general. A wide variety of achievement levels and attitudes exist among both e-learning and traditional learning. Although an illusory "typical learner" exists, a variety of factors, including students' gender, access to the internet, age, owning laptop, and motivation, could explain different reactions among the student population. Add to this the variety of modes that e-learning employs, and the data collected can be ambiguous at best. Whether students are involved in full-scale e-learning programs or experimenting online activities for a traditional class, their perception of the experience profoundly affects the process of education. Learning varies with each individual, as do preferences for the methods used to learn. Given the appropriate tools, students can become lifelong learners with a passion for knowledge. The challenge for educators is therefore the same as it has always have been: how to help students learn. The difference between the blackboard-bound classroom and the cyber-connected virtual classroom is just a matter of space, and integration therefore educators must learn how that space and integration helps to define student perceptions of future education. Findings from this research suggest future studies should focus on students' learning experiences as reflected in attitudes toward education

\section{References}

Ascough, R. (2002). Designing for online distance education: Putting pedagogy before technology. Teaching Theology and Religion, 5, 1729. 
Bame, S, Petersen, N, \& Wray, N.P. (1993). Variation in hemodialysis patient compliance according to demographic characteristics. Social Science \& Medicine, 37(8), 1035-1043.

Bartlett, J. E., II, Reynolds, K A., \& Alexander, M. W. (2000). A tool for online learning. Journal of Online Learning, 11(3 \& 4), 22-24.

Beatty, P. T, \& Mortera-Guiterrez, F. (2000). From research to practice in distance learning education: Strategies for fostering faculty development and improving instructional practice. ERIC Document Reproduction Service No. ED 437536.

Benek-Rivera, \& Matthews, V. (2004). Active learning with jeopardy: Students ask the questions. Journal of Management Education, 28(1), 104-118.

Blustain, Harvey, Philip Goldstein, and Gregory Lozier. (1999). "Assessing the New Competitive Landscape," in Dancing with the Devil, Editors: Richard N. Katz and Associates, Jossey-Bass Publishers, San Francisco.

Boser, R. Palmer, J, \& Daugherty, M. K. (1998). Student's attitudes toward technology in selected technology education programs. Journal of Technology Education, 10(1), 4-19.

Bransford, J. D, Brown, A. L., \& Cocking, R. R. (Eds.). (2000). How people learn: Brain, mind experience, and school committee on developments in the science of learning. Commission on Behavioural and Social Sciences and Education of the National Research Council, National Academy Press.

Brown, K. M. (1996). The role of internal and external factors in the discontinuation of off-campus students. Distance Education, 17(1), 44-71.

Carnevale, D. (2000). Study assesses what participants look for in high-quality online courses. Chronicle of Higher Education, 47(9), A46. Retrieved April 6, 2002 from Academic Search Elite database.

Carr, S. (2000). Two professors find that online chats are unpopular. The Chronicle of Higher Education, April 7 , 31-32.

Cifuentes, L. (1997). from sages to guides: a professional development study. Journal of Technology and Teacher Education, 5(1), pp. 67-77.

Coombs, S.J. \& Wong, P. (2000). Supporting student-centered learning with IT. In M.Williams (Ed), Integrating Technology into Teaching and Learning: concepts and application. Singapore, Prentice Hall, 230-249.

Crook, C.K. (2008). Web 2.0 Technologies for Learning: The current landscape-Opportunities, challenges and tensions. Coventry: Becta. [Online] Available: http://partners.becta.org.uk/upload-dir/downloads/page_documents/research/web2_technologies_learning.pdf (March 3, 2009).

Crotty, T. (2000 April 7). Constructivist theory unites distance learning and teacher education. [Online] Available: f http://edie.cprost.sfu.ca/it/constructivist-learning (May 12, 2001).

Dash, J. (2000). Computer ware introduces remotely hosted software for Internet testing service. Computer world, 34(88), 1, 4.

DfES. (2005). DfES e-learning strategy: Harnessing technology -Transforming learning and childrens' services. [Online] Available: http://www.dfes.gov.uk/publications/e-strategy/ (July 1, 2008).

Driscoll, M. \& Carliner, S. (2005). Advanced web-based training strategies. San Francisco: Pfeiffer.

Drucker, Peter. (1997). "An Interview with Peter Drucker," Forbes Magazine, March 10 pp.126-127.

Duffy, T. M., \& Cunningham, D. J. (1996). Constructivism: Implications for the design and delivery of instruction. In D. H. Jonassen (Ed.), Handbook of research for educational communications and technology. New York: Macmillan.

Dutton, W.H., P.H. Cheong, and N. Park. (2003). The social shaping of a virtual learning environment: The case of a university-wide course management system. Electronic Journal of e-Learning 2, no. 1.

Eble, K. (1994). Craft of teaching: A guide to mastering the professor's art (2ndedition), New York: Jossey-Bass. E-learning replaces classroom. (2003). Health Management Technology, 24(4), 50-51.

Frankola, K. (2001). Why online learners drop out. Workforce, 10, 52-60.

Golladay, R., Prybutok, V. \& Huff, R. (2000). Critical success factors for the online learner. Journal of Computer Information Systems, 40(4), 69-71. 
Hall, B. (2003). FAQs about e-learning. Retrieved August 15, 2003, [Online] Available: www.brandonhall.com/public/faqs2/faqs2.htm.

Hara, N. \& Kling, R. (2000). Students' distress with a web-based distance education course: An ethnographic study of participants' experiences. Information, Communication and Society, 3(4), 557-579.

Harrell, W., Jr. (1999). Language learning at a distance via computer. International Journal of Instructional Media, $26(3), 267-282$.

Hatfield, S. R., \& Gorman, K. L. (2000). Assessment in education-the past, present, and future. Assessment in Business Education National Business Education Association Yearbook, 38, 1-10. Reston,VA: National Business Education Association.

Haugen, S, LaBarre, J, \& Melrose, J. (2001). Online course delivery: Issues and challenges. Issues in Information Systems, 2, 127-131.

Heywood, J. (2000). Assessment in Higher Education. London: Jessica Kingsley Publishers

Hirumi, A. (2002). Student-centered, technology-rich learning environments (SCenTRLE): operationalizing constructivist approaches to teaching and learning. Journal of Technology and Teacher Education, 10(4), pp. 497-537.

Honebein, P. C. (1996). Seven goals for the design of constructivist learning environments. In B. G. Wilson (Ed.), Constructivist learning environments: Case studies in instructional design. Englewood Cliffs, NJ: Educational Technology Publications.

Huang, A.H. (1996-1997). Challenges and opportunities of online education. Journal of Educational Technology Systems, 25, 229-247.

Johnston, J., Killion, J., \& Oomen, J. (2005). Student satisfaction in the virtual classroom. The Internet Journal of Allied Health Sciences and Practice. 3. [Online] Available: http://ijahsp.nova.edu/articles/vol3num2/Johnston\%20-\%20Printer\%20Version.pdf (January 26, 2007).

Laine, L. (2003). Is e-learning effective for IT training? $T+D$, 57(6), 55-60.

McDonald, D. (1999-2000). Improved training methods through the use of multimedia technology. Journal of Computer Information Systems, 40(2), 17-20.

McEwan, B. (2001). Web-assisted and online learning. Business Communications Quarterly, 64(2), 98-103.

McLester, S. (2002). Virtual learning takes a front row seat. Technology and Learning, 22, 2436.

McMahon, J, Gardner, J, Gray, C., \& Mulhern, G. (1999). Barriers to computer usage: Staff and student perceptions. Journal of Computer Assisted Learning, 15, 302.

Malkowski, S.R., M.E. Thompson, and J.G. Theis. (2006). External factors associated with adopting a CMS in resident college courses. Internet and Higher Education, 9: 163-74.

Morgan. G. (2003). Course management system use in the University of Wisconsin system. Boulder, CO: EDUCAUSE Center for Applied Research (ECAR).

Ofcom. (2008). Social networking: A quantitative and qualitative research report into attitudes, behaviors and use. [Online] Available: http://www.ofcom.org.uk/advice/media_literacy/medlitpub/medlitpubrss/socialnetworking/report.pdf (April 5, 2008).

Oregon to Administer Standardized Tests on Computers. (2001). Electronic Education Report, 8(9), 2-7.

Pallof, R., \& Pratt, K. (2003). The Virtual Student: A Profile and Guide to Working with Online Learners. San Francisco, CA: Josey-Bass Publishers.

Picciano, A.G. (2002). Beyond student attitudes: Issues interaction, presence, and performance in an online course. Journal of Asynchronous Learning Networks, 6, 20-41.

Piccoli, G, Ahmad, R. \& Ives, B. (2001). Web-based virtual learning environments: A research framework and a preliminary assessment of effectiveness in basic IT skills training. MIS Quarterly, 25(4), 401-425.

Quitadamo, J. \& Brown, A. (2001). Effective teaching styles and instructional design for online learning environments. National Educational Computing Conference, July 25-27, 2001 (Chicago,IL). [Online] Available: http://confreg.uoregon.edu/NECC2001/program/research_pdf/Quitadamo.pdf (January 10, 2006). 
Rakes, G. (1996). Using the Internet as a tool in a resource based learning environment. Educational Technology, 1: (5), pp. 52-56.

Roblyer, M. D. (1999). Is choice important in distance learning? Journal of Research on Computing in Education, 32 (1), 157

Rumble, G. (2001). Reinventing distance education, International Journal of Lifelong Education, 20, 31-43.

Ryan, S. (2001). Is online learning right for you? American Agent \& Broker, 73(6), 54-58.

Sarason, Y, \& Banbury, C (2004). Active learning facilitated by using a game-show format or who doesn't want to be a millionaire? Journal of Management Education, 28(4), 509-519.

Scardamalia, M. (2002, April). Creative work with ideas: A luxury? Paper presented at the annual meeting of the American Psychological Association, New Orleans, LA.

Schumacher, P., \& Morahan-Martin, J. (2001). Gender, Internet and computer attitudes and experiences. Computers in Education, 17(1), 95-110.

Schoech, D. (2000). Teaching over the Internet: Results of one doctoral course. Research on Social Work Practice, 10, 467-487.

Serwatka, J. (2003). Assessment in on-line CIS courses. Journal of Computer Information Systems, 43(3), 16-20.

Shelly, G. B., Cashman, T. J, Gunter, R. E. and Gunter, G. A. (2004). Teachers discovering computers integrating technology into the classroom Thomson Course Technology, Boston, MA

The pay-offs of e-learning go far beyond the financial. (2003). HR Focus, 80(10), 7.

Volery, T. \& Lord, D. (2000). Critical success factors in online education. The International Journal of Education Management, 14(5), 216-223.

Wang, A.Y, Newlin, M.H, \& Tucker, T.L. (2001). A discourse analysis of online classroom chats: Predictors of cyber student performance. Teaching of Psychology, (28), 22222.

Watkins, R. (2005). Developing interactive e-learning activities. Performance Improvement, 44, 5-7.

Table 1. The independent-sample T test analysis

\begin{tabular}{|c|c|c|c|c|c|c|}
\hline Variable & & Mean & Std. Deviation & $\mathrm{t}$ & $\mathrm{df}$ & Sig. \\
\hline \multirow{2}{*}{ Gender } & Male & 4.2 & 0.46 & 12.98 & 256 & 0.000 \\
\cline { 2 - 5 } & Female & 2.9 & 0.59 & & & \\
\hline
\end{tabular}

Table 2. The independent-sample T test analysis

\begin{tabular}{|c|c|c|c|c|c|c|}
\hline Variable & & Mean & Std. Deviation & t & df & Sig. \\
\hline Owning PC & Yes & 3.9 & 0.51 & 5 & 256 & 0.000 \\
\cline { 2 - 6 } & No & 3.07 & 0.64 & & & \\
\hline
\end{tabular}

Table 3. The independent-sample T test analysis

\begin{tabular}{|c|c|c|c|c|c|c|}
\hline Variable & & Mean & Std. Deviation & $\mathrm{t}$ & $\mathrm{df}$ & Sig. \\
\hline \multirow{2}{*}{ Access } & Yes & 3.8 & 0.53 & 3 & 256 & 0.01 \\
\cline { 2 - 5 } & No & 3.1 & 0.64 & & & \\
\hline
\end{tabular}

